\title{
RELASI AGAMA, MAGI, SAINS DENGAN SISTEM PENGOBATAN TRADISIONAL-MODERN PADA MASYARAKAT PEDESAAN
}

\author{
Juhana Nasrudin \\ STAI Muhammadiyah Garut, Indonesia \\ nasrudin_juhana@yahoo.com
}

\begin{abstract}
This study examines the relation of Religion and the Traditional Medicine System to rural communities. The big conclusion of this dissertation shows that there are religious relations with the traditional medical system in the form of integration of religious functions into the traditional medicine system. Acculturation of religion and culture is evident in the traditional medicine system. The most important thing that characterizes traditional medicine is that at the practical level the traditional medical system in rural communities is inseparable from the magical and religious elements. So based on that religious function can be used as a function of therapy. This study uses qualitative methods, using two data sources. First, primary data obtained from document studies, field observations, In-depth Interview and Focus Group Discussion. The informant is obtained by Purposive and snowballing. Secondary data is supporting data obtained from books, journals, and magazines. To analyze the relationship between religion and the traditional medical system in rural communities, it was analyzed with three approaches to sociology, anthropology and psychology.
\end{abstract}

Key Words: Magi; Religion; Traditional Medicine System and Rural Society

\begin{abstract}
Abstrak
Penelitian ini mengkaji tentang relasi Agama dan Sistem Pengobatan Tradisional pada masyarakat pedesaan. Kesimpulan besar disertasi ini menunjukkan bahwa terdapat relasi agama dengan sistem pengobatan tradisional dalam bentuk integrasi fungsi agama kedalam sistem pengobatan tradisional. Akulturasi agama dan budaya nampak dalam sistem pengobatan tradisional. Hal terpenting yang menjadi ciri khas pengobatan tradisional dimana dalam tataran praktis sistem pengobatan tradisional pada masyarakat pedesaan tidak terlepas dari unsur magis dan agama. Maka berdasarkan hal itu fungsi agama dapat dijadikan sebagai fungsi terapi. Penelitian ini menggunakan metode kualitatif, dengan menggunakan dua sumber data. Pertama, data primer yang diperoleh dari studi dokumen, observasi lapangan, In-depth Interview dan Focus Group Discussion (FGD). Informan diperoleh secara Purposif dan snowballing. Data sekunder adalah data pendukung yang diperoleh dari buku, jurnal, dan majalah. Untuk menganalisa hubungan agama dan sistem pengobatan tradisional pada masyarakat maka pedesaan maka di analisis dengan tiga pendekatan sosiologi, antropologi dan psikologi.
\end{abstract}

Kata Kunci: Magi; Agama; Sistem Pengobatan Tradisional dan masyarakat Pedesaan

\section{PENDAHULUAN}

Agama diyakini sebagai suatu kepercayaan atau keyakinan terhadap Tuhan yang bersumber pada kitab suci sebagai doktrin yang kemudian dibawa dan simpaikan oleh sang juru selamat dan diaktualisasikan dalam bentuk ritus dan kultus. Berkenaan dengan hal itu, 
Para agamawan melihat Agama mengandung arti ikatan yang harus dipegang dan dipatuhi manusia. Ikatan yang dimaksud berasal dari suatu kekuatan yang lebih tinggi dari manusia sebagai kekuatan adikodrati yang tak dapat ditangkap dengan pancaindera, namun mempunyai pengaruh yang besar sekali terhadap kehidupan manusia sehari-hari (Koentjaraningrat, 1974).

Selain itu agama di sinyalir merupakan suatu kebutuhan prioritas di antara berbagai kebutuhan dalam kehidupan manusia, sehingga tidak heran agama sudah menjadi bagian integral dari kehidupan sosial dan kebudayaan manusia selama beriburibu tahun. Di semua kebudayaan, agama adalah bagian yang paling berharga dari perbendaharaan sosial. Ia melayani masyarakat dengan menyediakan sejak masa pertumbuhan berupa ide, ritual, sentimen, yang membimbing kehidupan setiap orang yang ada di dalamnya.

Ritual-ritual dan perilaku keagamaan pada dasarnya memfokuskan pada ketentuan cara-cara memperoleh keselamatan, melalui bentuk-bentuk penyembahan, do "a, atau meditasi yang memungkinkan orang beriman berkomunikasi dengan Tuhan atau tuhan-tuhan, dan bentukbentuk perilaku etis yang membawa kehidupan orang beriman atau komunitas beriman kepada keselarasan dengan nasib penyelamatan mereka. Sedangkan fungsi laten agama adalah sebagaimana agama mengidentifikasi kesuksesan seseorang dalam menghadapi sakit, atau dalam mencari keamanan materiil atau kemakmuran, melalui hadirnya spirit ketuhanan ke dalam diri orang beriman. Spirit ketuhanan hadir dan bekerja dengan memberinya kemampuan mengatasi rintangan yang menghalangi tujuan kehidupan mereka yang pada mulanya sering dipahami sebagai tujuan spiritual (Roy Wallis, 1977).

Sebagian masyarakat percaya bahwa pengobatan modern adalah cara pengobatan terbaik untuk bisa menyembuhkan sakit. Pengobatan modern identik dengan modernitas, karena menggunakan beragam kecanggihan alat, beragam obat kimiawi yang tentu saja ditemukan berdasarkan penelitian yang logis. Pengobatan modern sangat mengutamakan aspek rasionalitas, ilmu pengetahuan dan teknologi yang tinggi. Aspek-aspek yang berbau kebiasaan tanpa adanya bukti yang logis bukan bagian dari pengobatan modern.

Modernitas seringkali dikaitkan dengan kepercayaan terhadap dogma rasionalitas, sedangkan fenomena maraknya pencarian pengobatan tradisional pada masyarakat pedesaan. yang menggunakan jasa dukun dan kyai atau ustadz sering dipandang sebagai perilaku yang tidak rasional. Kapferer (dalam Alhumami, 2009) menjelaskan bahwa kepercayaan kepada dukun dan praktik perdukunan merupakan local beliefs yang terpatri dalam kebudayaan suatu masyarakat. Sebagai local beliefs, lanjut Kapferer, keduanya tak dapat dinilai dari sudut pandang rasionalitas ilmu karena memiliki nalar dan logika sendiri, rationality behind irrationality. Alhumami (2009), menyimpulkan bahwa praktik perdukunan bukan khas masyarakat tribal dan tradisional yang melambangkan keterbelakangan karena „bangsa maju dan modern di Eropa dan Amerika yang mengagungkan rasionalitas juga memiliki sejarah perdukunan, berwujud santet. Putra (2014:130) 
Dengan demikian seperti yang dijelaskan di atas bahwa tingkah laku manusia dalam menghadapi masalah kesehatan sifatnya terencana atau terpola dalam suatu sistem kesehatan yang merupakan salah satu bagian dari budaya masyarakat yang bersangkutan. Salah satu budaya masyarakat sunda yakni dalam sistem pengobatan penyakit yang di derita oleh masyarakat, pengobatannya menggunakan jasa dukun.

Masyarakat sunda sejak dulu sudah mengenal dukun sebagai tempat berobat sebelum adanya tenaga medis yang mengatasi keluhan-keluhan atau penyakit, maka dari itu budaya pengobatan dukun agar kiranya dapat dilestarikan keberadaanya. Serta dapat diwariskan kepada masyarakat sunda. Pewarisanya pun dapat dilakukan melalui keluarga dan dengan beriringnya waktu proses tradisi itu sendiri dapat berkembang melalui lembaga pendidikan dan lembaga sosial masyarakat dari sinilah masyarakat dibelajarkan dan akan mengetahui seberapa pentingnya tradisi itu untuk dipertahankan.

Warisan budaya pada intinya adalah suatu pengetahuan yang dapat berfungsi menghadapi tantangan kehidupan. Dalam masyarakat tradisional pengetahuan umumnya diperoleh dengan cara belajar dan mewarisinya secara turun temurun dari satu generasi ke generasi berikutnya. Sebagai salah satu unsur kebudayaan daerah yang bersifat universal yang telah diwarisi secara turun tenurun oleh masyarakat pendukungnya, salah satu diantaranya adalah pengetahuan yang berkenaan dengan kesehatan khususnya pengobatan tradisional (Ilham, 2012).

Setiap kelompok etnis relatif telah menguasai dan mengembangkan pengetahuan kesehatan. Pengetahuan kesehatan tradisonal dengan pengetahuan medis modern memiliki persamaan dan juga perbedaan, namun secara umum pengobatan kesehatan tradisional yang dikenal dan dipahami oleh dukun, kyai orang pintar dan lain sebaginnya berbeda dengan pengobatan kesehatan medis modern (Ilham, 2012).

Fenomena kehadiran pengobat tradisional atau spiritual telah sering diulas oleh media massa, namun penelitian yang membahas tentang relasi agama, magi dan agama kebanyakan kajian hanya seputar praktik perdukunan (Syuhudi 2013, Pelras 2006, Bennett 2005, Said 1996, Geertz 1983). Geertz (1983), misalnya, mengungkapkan bahwa dalam masyarakat tradisional, dukun adalah spesialis magi umum yang berguna untuk mengobati orang sakit, baik fisik maupun psikologis, meramal kejadian masa depan, penemu barang-barang hilang, pemberi jaminan tentang peruntungan yang baik, tidak segansegan mempraktikkan sihir berdasarkan permintaan klien.

Temuan Bennett (2005) di masyarakat Sasak menunjukkan keberdampingan sihir dan Islam. Bennet menemukan orang yang dianggap saleh, tapi sangat percaya dengan takhayul. Agama dan sihir memiliki fungsi masing-masing dalam masyarakat, sehingga tidak saling dipertentangkan. Pelras (2006) juga menggambarkan bahwa ritual praIslam juga dapat berdampingan dengan ritual Islam, meskipun proporsinya berbeda antara satu ritual dengan ritual yang lain. Ritual tersebut juga dipraktekkan oleh Muslim yang dianggap taat beribadah. Eksistensi pengobatan dukun masih tetap signifikan oleh masyarakat perkotaan 
seperti Makassar dan Bandung karena mereka mampu beradaptasi dengan lingkungan perkotaan (Said 1996), untuk mempertahankan eksistensi mereka (Syuhudi 2013).

Kajian yang terkait dengan pengobatan tradisional, seperti yang dilakukan Soegeng Reksodiharjo, (19911992), Muria Herlina (1996), Mulyono (1990), Notosiswoyo, Komang Ayu Henny Achjar (1994), M. Zein Rani (1993), dan Suhaeni Soedjatmiko (1991). Dari semua penelitian diatas belum „menyentuh"e pada aspek agama dan magi secara mendalam sehingga tidak ketemukan relasi dari agama, magi, dan sains. Selain itu pengobatannya hanya membahas pengobatan tradisional saja tanpa dikomperatifkan dengan keberadaan pengobatan modern yang pada realitasnya sudah mulai hadir pada masyarakat pedesaan.

Penelitian yang secara spesifik mengaitkan relasi agama, magis dan sains merupakan penelitian lanjutan yang mengembangkan penelitian sebelumnya sehingga berfungsi menyempurnakan penelitian penelitian sebelumnya.

Kontribusi baru dari penelitian ini akan menghasilkan sistem pengobatan yang disebut pengobatan tiga lapis yaitu pengobatan yang didasarkan pada penggunaan magi, agama dan sains.

Agama menurut pandangan Durkheim mendefinisikan agama sebagai "Suatu Sistem yang terpadu mengenai kepercayaan-kepercayaan praktek-praktek yang berhubungan dengan benda suci atau benda-benda khusus (terlarang) kepercayaankepercayaan dan praktek-praktek yang menyatu dalam satu komunitas yang disebut umat, semua berhubungan dengan itu.

\section{Durkheim} mengabstraksi munculnya agama dalam masyarakat yaitu dengan memisahkan antara yang sacral dan yang profan. Jika meminjam pemikiran Durkheim tersebut maka dalam pengobatan tradisional dapat dipisahkan kedalam tiga hal, yaitu: 1) Sakral, dalam artian disini adalah diambil dari ritual-ritual keagamaan yang merubah nilai-nilai moral menjadi simbol-simbol religious dimana dimanifestasikan menjadi sesuatu yang riil.

Masyarakat menciptakan agama dengan mendefinisikan fenomena tertentu sebagai sesuatu yang sakral dan sementara yang lain dianggap profan (kejadian yang umum atau biasa. Adapun hal yang sakral inilah yang dianggap sebagai suatu yang terpisah dari peristiwa sehari-hari yang membentuk esensi agama.

Begitupun dalam sistem pengobatan tradisional tidak dapat dipisahkan dari sesuatu yang di sakralkan. Hal tersebut disebabkan dalam prakteknya pengobatan tradisonal yang dilakukan masyarakat perdesaan disandarkan pada aspekaspek spritual dari agama. Salah satu contoh hal yang sakral dalam pengobatan dapat dilihat dari proses pengobatan yang dilakukan pengobatan dimana unsur religi atau agama senantiasa nampak terlihat dengan jelas masuk dalam proses pengobatan.

Seperti kepercayaan dan keyakinan masyarakat terhadap sang maha pencipta yang tercemin dalam proses ritual seperti pembacaan do de $^{\text {e }}$ atau jampi-jampi. 2) Profan, Profan yang dimaksud adalah peristiwa yang biasa terjadi dalam masyarakat dikehidupan sehari-harinya yang tidak memiliki nilai-nilai suci yang disakralkan. Yang profan ini dapat 
menjadi sakral jikalau masyarakat mengagungkan dan menyucikannya.

Dalam pengobatan yang disebut profan adalah penggunaan bendabenda tertentu yang dimaksud adalah benda yang berwujud fisiknya adapun keyakinan terhadap apa yang menjadi maunah dari benda tersebut termasuk hal yang sakral dalam sistem pengobatan. Yang termasuk hal profan dalam hal ini seperti benda atau tumbuh-tumbuhan yang jadikan bahan ramuan, benda petuah, air dan sebagainya. 3) Totemisme, yang dimaksud dengan totemisme disini adalah sistem agama dimana sesuatu, bisa binatang dan tumbuhan dianggap sakral dan dijadikan simbol klan.

Fungsi agama adalah peran agama dalam mengatasi persoalanpersoalan yang timbul di masyarakat yang tidak dapat dipecahkan secara empiris karena adanya keterbatasan kemampuan dan ketidakpastian. Sementara Thomas F O"Dea mengemukakan enam fungsi dari agama, yaitu; Pertama, sebagai pendukung, pelipur lara, dan perekonsiliasi. Kedua, sarana hubungan transendental melalui pemujaan dan upacara/ritual ibadat. Ketiga, penguat norma-norma dan nilai-nilai yang sudah ada. Keempat, pengoreksi fungsi yang telah ada. Kelima, pemberi identitas diri. Keenam, pendewasaan agama. Secara ringkas fungsi agama dikemukan oleh Hendropuspito sebagai fungsi edukatif, penyelamatan, pengawasan sosial, memupuk persaudaraan dan transpormatif (Kahmad, 2009).

\section{METODE}

Penelitian ini dilakukan di Kecamatan Kadungora Kabupaten Garut, menggunakan metode penelitian kualitatif, dengan dua sumber data.
Pertama, data primer yang diperoleh dari studi dokumen, observasi lapangan, In-depth Interview dan Focus Group Discussion (FGD). In-depth Interview kepada 20 orang yang terdiri dari Camat Kecamatan Kadungora, Kepala Desa pada Desa yang menjadi partisipan penelitian, tokoh masyarakat, pimpinan ormas Islam, Pengobat Tradisional dan Pasien yang melakukan pengobatan tradisional. FGD dilakukan kepada 4 orang pelaku pengobat tradisional. Pemilihan informan dilakukan secara Purposif dan metode snowballing. Kedua, data sekunder merupakan data pendukung yang diperoleh dari buku, jurnal, dan majalah. Untuk menganalisa hubungan agama dan sistem pengobatan tradisional pada masyarakat maka pedesaan maka di analisis dengan tiga pendekatan sosiologi, antropologi dan psikologi.

\section{RELASI AGAMA, MAGIS DAN SAINS DALAM SISTEM PENGOBATAN TRADISIONAL}

Jika diperhatikan dari keenam fungsi tersebut maka ada satu yang hilang yaitu agama berfungsi sebagai penyelamat yang selanjutnya disempurnakan oleh hendropuspito sebagaimana sudah disampaikan diatas. Namun dalam kajian disertasi ini akan memperjelas menguatkan apa yang disampaikan oleh ketiga ahli tersebut. Bahwa selain dari fungsi penyelemat agama juga berfungsi sebagai penyembuh terhadap penyakit yang diderita oleh masyarakat. Argumentasi ini di buktikan dengan hasil penelitian dilapangan yang menunjukkan bahwa ketika agama digunakan dalam terapi atau pengobatan maka akan berakibat sembuhnya penyakit tersebut. 
Argumentasi ini diperkuat pula oleh Jung (Carl Gustav Jung) yang mana dalam ia memasukkan unsur agama dalam terapinya. Hasilnya membuktikan bahwa agama berfungsi sebagai penyembuh agama penyembuh orang yang neurosis, manusia pada umumnya menderita neurosis karena kebingungan menemukan makna hidup, terutama berhadapan dengan kematian, dan pertanyaan yang penting itu tidak bisa dijawab oleh ilmu pengetahuan, tetapi oleh agama (Kahmad).

Sedangkan jika dianalisis dengan menggunakan teori batos atau teori batas akal yang disampaikan oleh J. Frezer. Ia mengemukan teori tentang perkembangan rasionalitas manusia. Menurutnya bahwa manusia awalnya memahami lingkungan pada tahapan ini menghasilkan kenyataan adanya praktik magi, kemudian dalam memahami lingkungan tidak dapat dijakau dengan magi maka selanjutnya agama datang dan digunakan untuk menjelaskan gejala-gejala alam, sehingga lahir ritual-ritual keagamaan. Dan tahapan selanjutnya adalah tahapan dimana ilmu pengetahuan mengambil alih kedua peran sebelumnya. Pada tahapan ini merupakan tahapan puncak perkembangan scientifik ilmiah (Kahmad).

Apa yang dikatakan oleh Frezer, terbukti dalam proses pembentukan pengobatan tradisional. Pertama-tama masyarakat pada era primitif melakukan pengobatan didasarkan pada pemahaman yang ia pahami dari lingkungannya seperti penggunaan magic, atau ramuan-ramuan yang ada dialam sekitarnya, kemudian hadir agama memberikan penjelasan tentang gejala-gejala alam sehingga masyarakat memfungsi unsur-unsur agama dalam

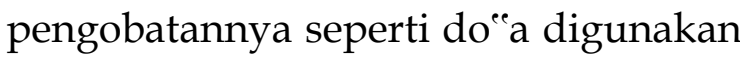
sebagai media terapi penyembuhan penyakit sebagaimana dijelaskan pada bab sebelumnya. Baru tahapan selanjutnya adalah melakukan pengobatan dengan menggunakan pendekatan ilmiah maka hadir lah pengobatan modern.

Keberadaan pengobatan modern dan tradisional pada tataran realitas tidak bisa dihilang tetapi sebenarnya dua hal yang saling membutuhkan. Pada suatu waktu pengobatan tradisional akan dibutuhkan bilamana penyakit tersebut tidak dapat disebuhkan dengan pengobatan modern, begitupun sebaliknya. Maka dengan demikian semestinya kehadiran pengobatan modern merupakan penyempurnaan pengobatan sebelumnya yang mesti ada secara bersamaan. Hal ini dikuatkan juga ioleh pendapat Malionowski yang mengatakan bahwa agama merupakan sumber kekuatan dalam menghadapi krisis termasuk dalam hal pengobatan.

Keberadaan sistem pengobatan tradisional pada masyarakat pedesaan yang berada di wilayah kecamatan Kadungora dapat di analisis dengan menggunakan teori batas akal yang dikembangkan J Freezer (Kahmad, 2009). Jika didasarkan pada teori ini maka ada tiga yang unsur yang mempengaruhi tentang keberadaan pengobatan tersebut. Adapun ketiga unsur tersebut ialah magic, agama dan sains. Pada mulanya pengobatan masyarakat pedesaan yang masih primitif menggunakan magis sebagai alat untuk melakukan pengobatan. Pada tahapan tersebut agama belum hadir, hal ini karena masyarakat masih menyandarkan kehidupannya pada alam. Alam oleh masyarakat primitif dianggap mempunyai kekuatan supranatural. Kemudian pada tahapan 
selanjutnya pemikiran manusia mengalami pengembangan sehingga mengenal keberadaan agama. Maka ketika agama hadir dan memasyarakat dalam kehidupan, maka sistem pengobatan tradisionalpun mulai dipengaruhi oleh unsur agama itu sendiri. Pada tahapan selanjutnya pemikiran manusia mengalami pengembangan lebih maju karena pada tahapan ini manusia mulai memberdayakan akalnya sehingga melahirkan sains. Maka ketika sains lahir sistem pengobatan manusia mulai mengalami puncak kemajuan. Pada tahapan ini merupakan tahapan lahirnya pengobatan modern.

Pengobatan modern seolah merupakan yang paling canggih yang ada pada zaman sekarang. Padahal pada hakikatnya tidak seperti itu, hal tersebut dikarenakan bahwa pengobatan modern juga terkadang tidak mampu mengobati beberapa penyakit yang diakibatkan oleh unsur magic atau mistis. Adapun penyembuhan atau pengobatan hanya dapat di lakukan oleh para pengobat tradisional dengan menggunakan magis atau agama.

Disinilah pentingnya sebenarnya mengintegrasikan magis, agama dan sains. Sehingga terbentuk suatu bentuk pengobatan yang satu sama lain saling melengkapi. Seorang pengobat modern haruslah menguasi magis dan agama. Sehingga dalam suatu waktu dapat digunakan dalam praktik pengobatan. Apa lagi agama sebenarnya sangat dibutuh kan dalam proses penyembuhan sebagaimana Gustav Jung lakukan dalam terapinya ternyata. Spiritualitas agama dapat mempengaruhi proses penyembuhan (Kahmad).

Para ahli psikolog melihat fenomena tersebut, hakikatnya sebagai stimulan untuk menyembuhkan pasien yang sakit. Adapun unsur terpenting dari agama yang harus diintegrasikan, yaitu aspek spiritual dari agama itu sendiri. Ada beberapa unsur spiritual yang seringkali dibutuh dalam pengobatan diantaranya; 1) Keyakinan akan kesembuhan, dan kesabaran dalam menerima penyakit, 2) Keshalehan dan keta"atan pada sang khaliq, dan 3) Do"a kepada sang khaliq. Lihat gambar 5.1. Dimana magic, agama dan sains diintegrasikan sehingga menghasilkan temuan baru yang akan ada diera sekarang.

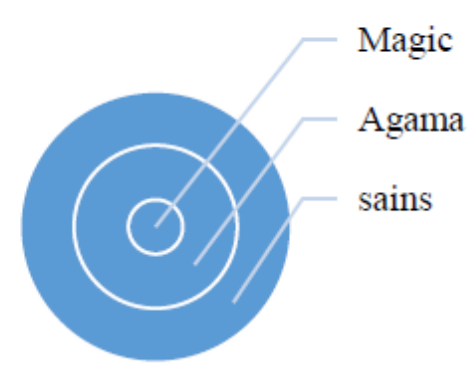

\section{Gambar : Pengobatan 3 Lapis}

Selanjutnya

Pengobatan Tradisional Masyarakat Pedesaan yang berada di Kecamatan Kadungora dipengaruhi oleh kepercayaan orang Sunda yang berhubungan dengan pemaknaan mereka atas alam lingkungan sekitarnya. Bagi mereka, hutan misalnya bukan hanya dihuni oleh hewan-hewan liar semata, melainkan dihuni pula oleh orangorang gaib, macam gaib, datu, dan sebagainya. Itulah sebabnya, alam (hutan, gunung, rawa, sungai, dan sebagainya) harus diperlakukan dengan baik, dan apabila hendak dimanfaatkan harus terlebih dahulu dilakukan ritualritual tertentu untuk penghormatan; permintaan izin; dan permohonan kesuburan tanah serta keberhasilan akan usaha yang dikerjakan. Dalam pepatah sunda ada peribahasa "Mipit 
kudu amit, ngala kudu bebeja" (mengakhir sesuatu harus pamit, mengambil sesuatu harus memberi tahu). Pada masa sebelum Islam memasyarakat pada wilayah penelitian. Masyarakat sekitar ketika akan memanen padi harus ada ritual yang oleh masyarakat disebut "nyuguh" (sesaji).

Biasanya orang Sunda memberi nasihat kepada anaknya untuk tidak bermain di tempat-tempat yang angker atau meminta ijin kepada para penunggu tempat angker agar terhindar dari marabahaya. Sehingga menjadi satu etika (sekaligus nasihat) yang diwariskan oleh orang tua bahari kepada anak cucunya dalam masyarakat Sunda, agar mereka berhati-hati apabila bepergian ke tengah hutan atau ke daerah-daerah tertentu yang dianggap angker dan jarang didatangi oleh manusia. Di samping itu, mereka juga diharuskan untuk meminta ijin kepada penghuni gaibnya yang berdiam di daerah tersebut dan biasanya dipanggil „Eyang atau Embah. ${ }^{1}$ Misalnya hendak mengambil kayu bakar atau menebang pohon di hutan: "Embah punten iyeu incu seja mipit, Mugi embah ngawidian tuang incu kangge nuar ieu tangkal". (embah mohon maaf saya cucu mu

1 Di samping digunakan oleh masyarakat Sunda untuk menyebut orang gaib yang menjadi penghuni atau penunggu tempat-tempat tertentu sebagai tanda atau panggilan penghormatan, kata Eyang dan Embah juga dipakai untuk menyebutkan seorang tokoh yang disegani karena ketinggian ilmunya, keulamaannya, kekuatan magis dan supranatural yang dimilikinya, dan atau kedudukan sosialnya yang tinggi hal ini didasarkan pada temuan dilapangan

2 Dalam Masyarakat Sunda, Peneliti dapatkan informasi bahwa selain membaca bismillah dan shalawat, umat Islam juga dianjurkan untuk membaca „7 ayat keselamatan ${ }^{\text {ee }}(7$ salam) agar terhindar dari segala gangguan makhluk gaib (dalam konteks ini disebut hantu karena sifatnya yang jahat dan mengganggu). Adapun ayat yang dimaksud mohon izin, semoga embah memberikan izin untuk cucumu ini untuk menebang kayu).

Tentu saja, semua itu ditujukan agar mereka terhindar dan tidak terkena bahaya, sakit atau gangguan orang gaib sebagaimana disebutkan di atas. Etika tak tertulis berupa pemahaman seperti ini kemudian berakulturasi setelah Islam datang. Di mana, Islam memang mengajarkan dan mengakui keberadaan makhluk gaib (setan atau jin) yang berdiam di hutan, di gunung, di lautan, padang pasir, dan sebagainya. Karenanya, sebelum memasuki daerah-daerah yang biasanya dihuni oleh bangsa jin, umat Islam dianjurkan untuk membaca bismillah dan shalawat kepada Nabi Muhammad Saw. ${ }^{2}$

Akulturasi tersebut juga menyentuh kepercayaan dan pemahaman terhadap pelbagai ritus yang lain, termasuk tatamba. Apabila sebelum Islam datang untuk ritual pengobatan tersebut dibacakan mantera, maka kemudian ia berubah dan dibacakan doa sebagai penggantinya atau ditambahkan kalimat syahadat pada akhir mantra; penggunaan ukiran kaligrafi yang menggantikan simbol penolak bala; wafak yang bertuliskan ayat-ayat

sebagai ayat keselamatan tersebut adalah ayat-ayat Alquran yang menyatakan tentang salaam atau keselamatan, kesejahteraan, kedamaian, sebagaimana yang tercantum dalam: QS. Maryam 33: "Dan kesejahteraan semoga dilimpah-kan kepadaku, pada hari aku dilahirkan, pada hari aku meninggal dan pada hari aku dibangkitkan hidup kembali". QS. Yaasin 58: "(Kepada mereka dikatakan): "Salam", sebagai ucapan selamat dari Tuhan Yang Maha Penyayang". QS. ash-Shaffat 79: "Kesejahteraan dilimpahkan atas Nuh di seluruh alam". QS. ashShaffat 109: "(yaitu) "Kesejahteraan dilimpah-kan atas Ibrahim". QS. ash-Shaffat 120: "(yaitu): "Kesejahteraan dilimpahkan atas Musa dan Harun". QS. ash-Shaffat 130: "(yaitu): "Kesejahteraan dilimpahkan atas Ilyas". QS. ash-Shaffat 181: "Dan kesejahteraan dilimpahkan atas para Rasul”. 
Alquran; Yaasin untuk penghalat (pembatas) agar terhindar dari gangguan makhluk gaib, dan sebagainya. Sehingga terjadi perpaduan antara unsur-unsur budaya dan kepercayaan yang dianut oleh masyarakat Sunda sebelum Islam datang dengan unsur-unsur Islam dalam ritual tatamba dimaksud.

Selain dari ketiga hal diatas ada juga yang mempengaruhi sistem pengobatan tardisional yaitu terkait dengan mitos. Pengertian Mitos, Menurut Van Peursen mitos adalah suatu cerita yang memberikan pedoman atau arah tertentu pada komunitas masyarakat (Abdullah Aly, Eny Rahma, 2007). Cerita cerita tersebut dapat berbentuk simbol-simbol yang memberi gambaran tentang suatu hal kebaikan dan keburukan, kahidupan dan kematian, dosa dan penyucian, perkawinan dan kelahiran, akhirat, surga, dan neraka. Dipandang dari segi keadaan mitos juga dapat diartikan dengan sesuatu yang erat kaitannya dengan hal-hal mistis di mana manusia merasa terkepung oleh kekuatankekuatan ghoib di sekitarnya, yaitu kekuasaan dewa-dewa alam raya atau kekuasaan kesuburan seperti yang trrdapat dalam mitologi primitive (Sujarwa, 2010).

Pada dasarnya mitos adalah merupakan tahapan perjalanan spiritual manusia dalam mencapai kebahagiaan dan ketentraman dalam kehidupannya di dunia. Mitos merupakan tahapan-tahapan manusia untuk menemukan sesuatu yang di yakini keberadaannya yaitu yang maha pencipta. Oleh karena manusia merasa makhluk paling lemah secara fisik, maka membutuhkan sesuatu dari luar dirinya untuk menjamin kehidupan yang sesui dengan tuntutan hidup. Manusia akan merasa gelisah dalam krnyataan terciptanya yang lemah di banding dengan makhluk lain.Untuk itu, maka manusia berusaha untuk menggali kesebenaran dari apa yang terdapat dari alam semesta demi mencari dari apa yang mereka sebut kebenaran.Perjalanan spiritual inilah yang kemudian di gambarkan menjadi suatu yang nyata melalui cerita-cerita fiksi. Cerita-cerita tersebut membentuk alur yang sistematis dan patent (Sujarwa, 2010).

Dalam alam pemikiran mistis, antara manusia dan alam, baik itu alam fisik, metafisik dan sosial merupakan suatu hal yang berkaitan erat dan saling memiliki ketergantungan. Manusia merasa terkepung oleh kekuatankekuatan luar biasa yang terdapat dalam alam yang tida tampak, yaitu alam para dewa. Dalam alam mistis manusia belum merasa sebagai makhluk individu yang bulat, akan tetapi masih terkungkung oleh gambaran-gambaran dan perasaanperasaan ajaib yang mereka resapi sebagai roh-roh dan daya-daya dari luar (Sujarwa, 2010). Untuk itulah dalam masyarakat mistis tidak akan pernah sepi dengan ritual. Perilaku seperti inipun di wariskan secara turun temurun sehingga menjadi tradisi.

Alam pemikiran tersebut kemudian membentuk suatu kesadaran individu maupun kesadaran bersama dalam suatu komunitas masyarakat dalam upaya mencari kebenaran untuk memenuhi kepuasan batin. Proses seperti ini memberikan bukti bahwa manusia mulai menentukan arah kepercayaannya atau teologi pada kekuatan para dewa.

Kesadaran bersama tersebut memiliki dua macam sifat yaitu; eksterior dan constrain (Margono, 1982). Eksterior mengandung arti bahwa kesadaran kolektif berdiri di luar 
kesadaran itu sendiri sehingga cenderung kesadaran tersebut bersifat constrain atau di paksakan. Kesadaran berbau mistis tersebut di wariskan secara turun temurun dalam bentuk mitos sebagai unsur tradisi kepercayaan. Bentuk kepercayaan sebagai titik harapan kelayakkan hidup bermasyarakat mistis yang sering di pentaskan dalam berbagai kesenian maupun ruwatan. Mitos-mitos tersebut menggiring pada perilaku yang memaksa untuk melakukan apa yang mereka anggap sebagai sebuah kebenaran sejati.

Tradisi kepercayaan adalah konstensi dari Pengaruh mitos yang telah mengakar dalam masyarakat. Dengan kepercayaan manusia dapat merasa telah mencapai kehidupan yang sebenarnya. Menurut teori batos (J.G Frazer) bahwa manusia mempunyai keterbatasan akal sehingga membutuhkan kekuatan lain yang lebih dominan (Sujarwa, 2010).

Keberadaan mitos dalam masyarakat menjadi sangat penting melihat konteks mitos yang terbentuk menjadi kepercayaan yang bersifat tradis. Karena kepercayaan merupakan bagian yang terpenting dalam kehidupan individu dan masyarakat. Manusia pada dasarnya merupakan suatu komunitas yang memiliki habitat kehidupan yang sama, yaitu dalam keyakinan pada suatu kepercayaan. Oleh sebab itu mitos menjadi suatu hal yang sangat fenomenal di tengahtengah masyarakat primitif.

Bagi masyarakat modern mitos, sudah tidak lagi menjadi hal yang fenomenal melainkan hanya dianggap sebagai peninggalan budaya yang tergolong dalam kekuatan daya seni. Akan tetapi, anggapan inipun bukan berarti mengeneralisasi dari kesemua masyarakat modern.Karena sebagian dari masyarakat modern masih terdapat suatu komunitas yang berpegang teguh dalam tradisi mitos.Misalnya di sebagian pulau Jawa di bagian selatan yang masih mempercayai tentang penguasa laut kidul. Di bagian pulau Jawa tersebut masih sering menjumpai ritual-ritual dengan membawa sesaji ke tepi pantai sebagai persembahan pada sang ratu penguasa laut.

Secara umum di dunia modern mitos mengalami degradasi yang signifikan. Hal itu di sebabkan karena dunia modern adalah termasuk dari bagian dari tahapan fungsional yang cenderung pada penggunaan rasio sehingga sesuatu yang irrasional seperti halnya mitos hanya akan menjadi karya masa lalu dan tidak layak pakai. Mitos raksasa memakan bulan yang menyebabkan gerhana bulan telah di gantikan dengan teori astronomi.Lambang-lambang mitos yang merupakan petunjuk kebenaran menjadi karya seni yang tidak berarti lagi.

\section{Penggunaan Magic dan Agama dalam Praktik Pengobatan Tradisional}

Magi dan agama adalah dua hal yang berbeda. Magi bertujuan mencapai hubungan dengan kekuatan alam untuk kepentingan pribadi, sedangkan agama berusaha menjalin hubungan dengan makhluk-makhluk rohani yang lebih dari sekadar kekuatan impersonal (Malinowski, Bronislaw, 1948). Agama berorientasi ketundukan (permohonan), sedangkan magi adalah pemaksaan kehendak atau perintah (Peursen, C.A. Van, 1988). Baal berpandangan bahwa jika magi dimaknai sebagai "tindakan-tindakan ritual sederhana yang diarahkan pada suatu efek konkret"e, maka do"a untuk memohon sesuatu pun merupakan bagian dari magi (Baal, J. Van, 1987). 
Weber juga menyatakan sulit memisahkan secara tegas antara magi dan agama, jika sekadar menggunakan parameter bahwa magi menggunakan kekuatan yang memaksa kekuatan adikodrati, sedangkan agama mengandalkan permohonan kepada Tuhan (Weber, Max, 2012). Weber mencontohkan dua unsur ritual dalam agama, seperti do"a dan penyembelihan kurban, sebagaimana yang dilakukan oleh para pengobat tradisional. Menurut Weber, kedua ritual ini tetap memiliki akar dalam magi, sebabagama pada praktiknya, tetap mengandung sejumlah besar komponen magi.

Meski magi dan agama sulit dibedakan, namun menurut saya tetap dapat dibedakan paling tidak pada aspek tujuan dan kemampuan „menjual kepastian"e. Pada kedua aspek tersebut, praktik yang dilakukan pengobat tradisional lebih dekat dengan magi daripada agama. Pada aspek tujuan, zikir yang digelar pengobat tradisional berorientasi instrumental; menyembuhkan pasiennya dalam menangani penyakitnya, bukan sepenuhnya dalam rangka beribadah. Dalam menjalankan praktiknya, pengobat tradisional terkesan „memaksakan kehendak ${ }^{\text {ee kepada }}$ Tuhan, misalnya, dengan penggunaan istilah do"a yang „dibayar kontan (oleh Tuhan). Ia juga menggunakan sarana „kurban 99 ekor ayam ${ }^{\text {ee }}$ atau dalam istilah perdukunan istilahnya tumbal. sebagai instrumen transaksi dengan kekuatan yang bersifat adikodrati. Selain itu, pengobat tradisional juga menawarkan kepastian kemenangan melalui formula perbandingan antara suara yang ingin diraih dan jumlah pembaca zikir „1000:250" .

Kedekatan praktik para pengobat tradisional dengan magi semakin jelas, jika merujuk pendapat
Frazer (1958:56), bahwa ahli magi lebih dekat dengan ilmuwan daripada agamawan. Ahli magi dan ilmuwan menganggap rangkaian kejadian sebagai sesuatu yang pasti dan mengikuti aturan dengan sempurna, terbatasi oleh hukum-hukum yang tidak berubah, yang operasinya dapat diramalkan dan diperhitungkan dengan tepat.

Praktik yang dijalankan oleh pengobat tradisional sebagai pelaku pengobatan spiritual memiliki beberapa kesamaan dengan praktik pengobatan yang didasarkan pada sains. Hanya bentuk yang berbeda. Seperti do"a dan penggunaan mediaa tertentu yang dijadikan sebagai obat. Jika dalam pengobatan modern resepnya berupa obat-obatan sintetis generik kimiawi. Sedangkan dalam pengobatan tradisional do"a dan ramuan tradisional.

\section{Perkembangan Tradisional}

Pengobatan

Didasarkan pada perkembangan akal manusia maka sistem pengobatan mansusia mengalami perkembangan dari primitif tradisional menuju pengobatan modern ilmiah modern. Ada beberapa tahapan perkembangan sistem pengobatan yang ada pada masyarakat baik di pedesaan ataupun di perkotaan, antara lain sebagai berikut:

1) Tahap irasionalisme dini

Ada sebagian orang yang percaya bahwa mereka sakit karena perbuatan makhluk-makhluk halus dan cara yang cenderung mereka lakukan adalah dengan melakukan pemujaan, mencari dukun, memberikan sesajian,dll.

2) Tahap irasionalisme fajar

Kepercayaan masyarakat akan adanya kekuatan gaib yang dimiliki oleh dukun membuat orang-orang 
dapat melakukan berbagai hal seperti membuat orang lain sakit atau melakukan guna-guna. Namun terlepas dari hal tersebut,ada juga dukun yang menggunakannya untuk menolong orang yang dikenal dengan white magic dan ada juga yang dikenal dengan black magic yang bersifat mengganggu. Dan karena alasan tersebut, sering terjadinya "pertempuran" kekuatan antara dua aliran tersebut yang berdampak pada tubuh manusia.

3) Tahap rasionalisme awal

Adanya kekuatan penyembuh penyakit, kekuatan peyegar yang secara alamiah terdapat di alam ditekuni oleh sebagian dukun. Mereka tidak tahu apa yang menyebabkan orang sakit, namun mereka mengetahui bahan alamiah apa yang dapat menyembuhkan penyakitpenyakit orang.

4) Tahap rasionalisme lanjut

Dalam tahap ini, mucullah dokter sebagai pengganti dukun. Keberadaan jamu pun digantikan oleh obat. Masyarakat tidak lagi percaya pada sesuatu yang bersifat tidak objektif dan yang tidak dapat dinalar berdasarkan fakta. Kekuatan-kekuatan alam terdahulu akhirnya menumbuhkan ilmu pengetahuan yang rasional, realistis, objektif dan dapat dinalar berdasarkan fakta.

Pemanfaatan berkaitan dengan kepercayaan masyarakat terhadap sesuatu hal. Giddens dalam (Damsar, 2009:187-193) selanjutnya membagi kepercayaan dapat tumbuh dan berkembang dalam dua lingkungan yakni pada masyarakat pramodern dan modern. Masyarakat pramodern yang dimaksudkan Giddens disini adalah bukan masyarakat yang benar-benar terisolasi melainkan juga masyarakat yang sedang menuju masyarakat industri atau masyarakat transisi.
Dalam masyarakat modern kepercayaan dapat tumbuh dan berkembang pada sistem abstrak seperti transaksi uang dan etika profesional, juga dapat berkembang pada relasi personal seperti persahabatan, yang terakhir adalah pada orientasi masa depan seperti misalnya kontrak, atau kontrak bisnis. Sedangkan dalam masyarakat pramodern kepercayaan dapat tumbuh dalam empat lingkungan yakni:

1) Hubungan kekerabatan

Menurut Giddens maka pengobatan tradisional dapat dilihat sebagai bentuk kepercayaan masyarakat karena hubungan dengan para pelaku pengobatan (Damsar, 2009). Masyarakat Sunda pada dasarnya semua memiliki hubungan kekeluargaan. Pemilihan pengobatan tradisional dalam hal ini dikarenakan hubungan pengguna obat tradisional dan pelaku pengobatan. Pelaku pengobatan dalam hal ini bisa saja orang tua, atau pengobat tradisional. Seseorang akan percaya pada orang tuanya yang melakukan pengobatan kepadanya. Hal ini juga berlaku pada masyarakat pedesaan yang berada di Kecamatan Kadungora dimana pelaku pengobatan masih memiliki hubungan kekerabatan terutama ke pengobat tradisional yang ditandai dengan keberadaan silsilah pengobatan yang turun temurun.

2) Komunitas masyarakat lokal

Giddens melihat tempat sebagai sebuah hubungan yang dapat menimbulkan persahabatan (Damsar, 2009), oleh karenanya dapat menumbuhkan kepercayaan. Dalam hal ini komunitas yang dimaksudkan dalam hal ini adalah hubungan sesama pengguna pengobatan tradisional yang sama-sama tinggal di satu desa. Kepercayaan kepada pengobat 
tradisional juga dipengaruhi oleh pengalaman masyarakat yang melihat pengobat tradisional menyembuhkan berbagai penyakit orang lain sebelumnya.

3) Kosmologi religius

Hal ini terlihat dari kepercayaan masyarakat kepada penyebab penyakit yang disebabkan oleh faktor gaib seperti roh halus atau perlakuan orang lain melalui medium tertentu. Masyarakat hanya percaya kepada pengobat tradisional untuk mengobati tipe penyakit ini, karena pada dasarnya pengobatan medis modern tidak dianggap mampu mengobati penyakit tipe personalistik. Masyarakat pedesaan yang berada di Kecamatan Kadungora yang mayoritas dari kalangan Suku Sunda masih mempercayai adanya penyakit yang disebabkan oleh medium roh yang hanya dapat disembuhkan melalui guru (pengobat tradisional).

4) Tradisi

Tradisi diartikan sebagai sebuah rutinitas atau perilaku yang dilakukan berulang-ulang oleh suatu masyarakat tertentu. Makna aktivitas rutin berada dalam penghormatan atau pemujaan yang melekat dalam tradisi dan dalam kaitan antara tradisi dan ritual. Oleh karenanya dalam tradisi juga kepercayaan dapat tumbuh dan berkembang. Masyarakat percaya kepada pengobatan tradisional karena melihat dan berdasarkan pengalaman orang tua atau nenek moyang mereka yang berhasil menyembuhkan orang lain. Hanya saja berdasarkan temuan data bahwa ritual tradisional tidak ditemukan lagi karena pengaruh nilainilai agama dimana dianggap sebagai hal yang dilarang agama. Kepercayaan terhadap pengobatan tradisional dalam hal ini dapat diartikan sebagai warisan nenek moyang.
Berdasarkan keempat jenis tempat bertumbuhnya kepercayaan masyarakat tradisional tersebut, tiga diantara masih merupakan tempat bertumbuhnya kepercayaan terhadap pengobatan tradisional. Ketiga hal tempat tersebut antara lain hubungan kekerabatan masyarakat Pedesaan disekitar lokasi penelitian terutama antara pemakai obat dan pengobat tradisional yang dikenal dengan hubungan tujuh garis keturunan dalam istilah orang sunda ada tujuh turunan. Kedua, komunitas masyarakat lokal, sebagai sebuah desa antara warga memiliki interaksi yang cukup frekuensinya tidak hanya pada sewaktu pengobatan melainkan juga dalam hal kegiatan pertanian dan pesta-pesta adat. Ketiga, kosmologi religius, hal ini meskipun semakin menipis karena pengaruh perkembangan agama Islam namun kepercayaan akan penyebab penyakit dari roh halus masih ditemui dan diyakini hanya dapat disembuhkan oleh pengobat tradisional. Namun yang terakhir, pada tradisi hal ini sudah jarang ditemukan karena masyarakat pedesaan yang berada di Kecamatan Kadungora sudah mulai sedikit demi sedikit meningggalkan tradisi-tradisi yang berkaitan dengan pengobatan tradisional dan beralih ke pengobatan modern.

Pemanfaatan dalam hal ini berarti segala upaya pengolahan pengetahuan mengenai metode pengobatan tradisional. Berdasarkan hasil penelitian di lapangan maka dapat dijelaskan bahwa bentuk-bentuk pemanfaatan pengobatan tradisional tersebut terbagi kedalam beberapa bentuk antara lain sebagai pemanfaatan sumber daya alam yang ramah lingkungan, pemanfaatan untuk mengobati diri sendiri, mengobati 
anggota keluarga atau tetangga dan sebagai sumber ekonomi tambahan.

Pemanfaatan sumber daya alam yang ramah lingkungan, Ramuan yang digunakan pada pengobatan tradisional di pedesaan yang berada di Kecamatan Kadungora adalah ramuan yang berasal dari unsur nabati (tumbuh-tumbuhan), hewani dan bahan mineral alam. Sumber ramuan tumbuhan yang digunakan umumnya dari hutan disekitar desa.

\section{Paranormal dalam Pandangan Islam Puritan dan Sinkretis}

Sebanyak $99 \%$ masyarakat pedesaan yang berada di Kecamatan Kadungora beragama Islam (BPS, 2015). Hal tersebut tidak serta merta membuat sistem kepercayaan lokal sebelum masuknya Islam turut punah. Pelras (2006:216) menyebut masuknya Islam menyebabkan terjadinya "sinkretisme esoteris' dan "sinkretisme praktis'. Sinkretisme esoteris adalah ajaran aliran kepercayaan terjadi pada periode awal Islamisasi, disebarkan melalui teks-teks yang sebagian besar lisan (meskipun ada pula yang tertulis), berisi ajaran yang mengawinkan sufisme Islam dengan konsep ketuhanan (teologi) dan konsep mengenai alam semesta (kosmologi) pra-Islam Bugis. Sinkretisme praktis yaitu sikap beragama tanpa mementingkan pemahaman ilmu agama (Pelras 2006:219), perpaduan sistem kepercayaan dalam berbagai ritual keseharian masyarakat. Sistem kepercayaan tersebutlah yang mewarnai praktik pengobatan tradisional yang dilakukan oleh para pengobat tradisional yang ada pada masyarakat pedesaan.

Padahal, jika menggunakan pendekatan puritan dalam memahami Islam, seharusnya paranormal/dukun tidak lagi memiliki tempat dalam sistem kepercayaan masyarakat pedasaan yang berada di Kecamatan Kadungora. Sikap puritan ini ditunjukkan oleh Wakil Ketua Pimpinan Wilayah Muhammadiyah Kadungora K.H. Halim Basarah:

Sesungguhnya mendatangi dukun dan tukang ramal untuk menanyakan sesuatu kepadanya berkaitan dengan sakit, nasib masa depan, atau untuk mengabarkan sesuatu yang gaib seperti barang hilang, dan yang semisalnya tidak diperbolehkan dalam Islam. Hukumnya haram. Apalagi kalau sampai meyakini dan membenar-kan apa yang mereka katakan. Karena sesuatu yang mereka katakan mengenai hal-hal yang gaib itu hanya didasarkan atas perkiraan belaka, atau dengan cara mendatangkan jin, dan meminta tolong kepada jin-jin itu tentang sesuatu yang mereka inginkan. (K.H. Halim Basarah, 18 Agustus 2018).

Pandangan K.H. Halim Basarah tersebut merujuk pada beberapa pandangan Al-Qurean berikut:

Katakanlah, tidak ada seorang pun di langit dan di bumi yang mengetahui perkara yang ghaib kecuali Allah (QS. An-Naml:65).

Katakanlah, „Aku tidak berkuasa menarik kemanfaatan bagi diriku dan tidak (pula) menolak kemudharatan kecuali yang dikehendaki Allah. Dan sekiranya aku mengetahui perkara yang ghaib, tentulah aku membuat kebajikan sebanyak-banyaknya dan tidak akan ditimpa kejahatan dan aku tidak lain hanyalah pemberi peringatan, dan pembawa berita gembira bagi orangorang yang beriman (QS. Al-A'raf: 188).

Dan menurut Hadis bahwa Nabi Muhammad saw:

Kunci perkara ghaib itu ada 5, tidak ada seorang pun yang mengetahuinya melainkan Allah, Tidak ada yang mengetahui (takdir) apa yang 
di dalam kandungan selain Allah, tidak ada yang mengetahui apa yang akan terjadi esok selain Allah, tidak ada seorang pun yang mengetahui (dengan pasti) kapan hujan akan turun kecuali Allah, dan tidak ada seorang pun yang mengetahui di bumi mana dia akan mati selain Allah, dan tidak ada yang mengetahui kapan terjadinya hari kiamat kecuali Allah (HR. Bukhari).

Ayat Al-Qurean dan Hadits yang disitir oleh K.H. Halim Basarah diatas menunjukkan bahwa dalam pandangan Islam puritan, kehadiran para-normal dan dukun dianggap bertentangan dengan Islam. Namun, sebagaimana diingatkan Pelras, Islam yang hadir dalam begitu banyak aspek kehidupan orang Sunda memiliki gambaran yang jauh lebih kompleks dalam praktiknya (Pelras 2006:209-210), yang tak dapat dipandang secara hitam putih atau dipisahkan antara Islam dan budaya setempat. Demikian pula praktik yang dilakoni oleh paranormal yang berperan sebagai pengobat tradisional, meski mengklaim melandaskan diri pada Islam, tetapi mereka juga tidak menafikan sistem kepercayaan yang telah hadir sebelum kedatangan Islam.

Meski magi dan agama sulit dibedakan, namun menurut saya tetap dapat dibedakan paling tidak pada aspek tujuan dan kemampuan „menjual kepastian "e. Pada kedua aspek tersebut, praktik yang dilakukan para pengobat tradisional di pedesaan lebih dekat dengan magi daripada agama. Terlebih lagi ketika Islam belum masuk maka penggunaan faktor magis lebih dominan digunakan baru kemudian setelah agam dan sains hadir sebagian masyarakat mulai beralih menggunakan agama dan sains.

Tetapi kendatipun demikian sebenarnya pengobatan tradisional dengan melibatkan unsur magi dan agama sebenarnya tidak akan hilang pada kehidupan masyarakat pedesaan., walaupun pengobatan modern yang menggunakan unsur sains mulai merambah pada kehidupan masyarakjat. Sebenarnya keberadaan magi, agama dan sains tidak akan bisa dinapikan kerana pada tataran praktiknya ketiga hal tersebut akan dapat berjalan bersama-sama.

\section{KESIMPULAN}

Penelitian ini menghasilkan beberapa kesimpulan sebagai berikut:

1. Masyarakat Pedesaan yang berada di Kecamatan Kadungora masih memanfaatkan sistem pengobatan tradisional. Tetapi walaupun demikian kehadiran pengobatan modern yang didasarkan pada sains sudah dimanfaatkan pula oleh masyarakat pedesaan seperti dengan keberadaan puskesmas di desa-desa yang merupakan cabang pembantu bagi Puskesmas yang berada di wilayah Kecamatan; dan

2. Praktek pengobatan tradisional dalam prakteknya menggunakan unsur magi, dan agama, hal tersebut dikrenakan keterbatasan pemahaman atau pendidikan dan ekonomi masyarakat dalam hal pencarian. Sehingga masyarakat lebih praktis menggunakan jasa pengobat tradisional dalam pencarian pengobatannya. 
DAFTAR PUSTAKA

Volume 2 Nomor 1 Tahun 2019

Adams, Cindy (2007) Soekarno Penyambung Lidah Rakyat Indonesia, Yogyakarta: Media Pressindo.

Alhumami, Amich (2009) Dukun Politik, http://www.bernardsimamora.com/dukundan-politik, diakses tanggal 3 Februari 2014.

Ardhianto, Imam (2012) Hubungan Relasional dan Ontologi Moralitas: Meninjau Beberapa Tulisan Antropologi Mengenai Ritus Kurban, dalam Tony Rudiansjah (ed.) Antropologi Agama: Wacanawacana Mutakhir dalam Kajian Religi dan Budaya. Jakarta: UI Press, 109-126.

Baal, J. Van (1987) Sejarah dan Pertumbuhan Teori Antropologi Budaya (Hingga Dekade 1970). Diterjemahkan oleh J. Piry. Jakarta: PT. Gramedia.

BPS (2015) Sulawesi Selatan Dalam Angka 2015. Makassar: Badan Pusat Statistik Provinsi Sulawesi Selatan.

Bakti, Andi Faisal (2007) Kekuasaan Keluarga di Wajo, Sulawesi Selatan, dalam Henk Schulte Nordholt, Gerry van Klinken, dan Ireen Karang-Hoogenboom (eds.) Politik Lokal di Indonesia, Jakarta: KITLV Jakarta dan Yayasan Obor Indonesia, 491505.

Bennett, Linda R. (2005) Women, Islam and modernity: Single Women, Sexuality and Reproductive Health in Contemporary Indonesia. London and New York: Routledge Curzon.

Comte, Auguste (2000) The Positive Philosophy, London: Batoche Books.

Eriksen, Thomas Hylland (2009) Antropologi Sosial dan Budaya: Sebuah Pengantar. Maumere: Penerbit Ledalero.

Fahmid, Mujahidin (2011) Pembentukan Elite Politik di dalam Etnis Bugis dan Makassar Menuju Hibriditas Budaya Politik.Disertasi. Bogor: Sekolah Pascasarjana Institut Pertanian.

Frazer, James (1958) The Golden Bough (Abridged Edition). New York: Macmillan.

Geertz, Clifford (1983) Abangan, Santri, Priyayi dalam Masyarakat Jawa. Jakarta: PT. Dunia Pustaka Jaya.

Goffman, Erving (1959) The Presentation of Self in Everyday Life.New York: Double Day. Halim, Abdul (2014) Politik Lokal: Pola, Aktor dan Alur Dramatikalnya, Yogyakarta: LP2B. Merdeka (2013) Garansi Insya Allah Jadi, Dukun Politik Ngaku Keturunan Nabi,http: //www.merdeka.com/peristiwa/garansiinsya-allah-jadi-dukun-politikngakuketurunan-nabi.html, diakses tanggal 9 Februari 2014.

Tribun Timur (2013) Jimat Maccaleg Rp10 M, 23 Oktober, 17.

Haluan (2012) Jelang Pilkada Dukun Laris, http:/ / harianhaluan.com/index.php/khas/1 1782-jelang-pilkada-dukun-laris, diakses tanggal 3 Februari 2014.

Homans, George (1974) Elementary Forms of Social Behavior.New York: Harcourt Brace Jovanovich.

Idrus, Nurul Ilmi (2003) To Take Each Other: Bugis Practice of Gender, Sexuality and Marriage. Disertasi. Canberra: The Australian National University.

Malinowski, Bronislaw (1948) Magi, Science and Religion, and Other Essays, Illinois: The Free Press.

Manguelle, Danielle Etounga (2006) Perlukah Afrika Sebuah Program Penyesuaian Budaya?, dalam Lawrence E. Harrison dan Samuel P. Huntington (eds.) 
Hanifiya: Jurnal Studi Agama-Agama

ISSN 2089-8835

Volume 2 Nomor 1 Tahun 2019

Kebangkitan Peran Budaya: Bagaimana Nilai-nilai Membentuk Kemajuan Manusia. Jakarta: LP3ES, 111-128.

Pelras, Christian (2006) Manusia Bugis, Jakarta: Nalar kerjasama dengan Forum Jakarta Paris.

Peursen, C.A. Van (1988) Strategi Kebudayaan, Yogyakarta: Kanisius.

Putra, Juma D. (2014) Dunia Batin 2 Macan Asia: Pengalaman-pengalaman Spiritual Bung Karno dan Pak Harto.Yogyakarta: Penerbit Palapa.

Pritchard, Evans (1940) The Nuer: A Description of the Modes of Livehood and Political Institutions of a Nilotic People. Oxford: Clarendon Press.

Rakyat Sulsel., 2014. Jasa Paranormal Bayangi Para Caleg, 23 Februari, 1.

Roth, Dik (2007) Gubernur Banyak, Provinsi Tak Ada: Berebut Provinsi di Daerah Luwu-Tana Toraja di Sulawesi Selatan, dalam Henk Schulte Nordholt dan Gerry van Klinken (eds.) Politik Lokal di Indonesia.Jakarta: KITLV Jakarta dan Yayasan Obor Indonesia, 154-189.

Sahlan, Muhammad (2010) "Dukun dan Politik": Peran Dukun Dalam Pemilukada di Banyuwangi Tahun 2010, http://etd.ugm.ac.id/index.php?mod=penel itian_detail\&sub=PenelitianDetail\&act=vi

ew\&typ=html\&buku_id=58877\&obyek_i d=4, diakses tanggal 3 Februari 2014.

Said, Basir (1996 Dukun, Suatu Kajian Sosial Budaya tentang Fungsi Dukun Bugis Makassar di Kotamadya Ujung Pandang. Tesis. Jakarta: Universitas Indonesia.

Syuhudi, Irfan (2013) Etnografi Dukun: Studi Antropologi tentang Praktik Pengobatan Dukun di Kota Makassar. Tesis. Makassar: Program Pascasarjana Universitas Hasanuddin.

Solihat, Ade (2012) Memahami Bahasa Agama dalam Perspektif Antropologi, dalam Tony Rudiansjah (ed.) Antropologi Agama: Wacana-wacana Mutakhir dalam Kajian Religi dan Budaya. Jakarta: UI Press, 6970.

Weber, Max (2012) Sosiologi Agama: A Handbook. Diterjemahkan oleh Yudi Santoso. Yogyakarta: IRCiSoD. 